This item was submitted to Loughborough's Research Repository by the author.

Items in Figshare are protected by copyright, with all rights reserved, unless otherwise indicated.

\title{
Austerity in public transport in Europe: the influence of governance
}

PLEASE CITE THE PUBLISHED VERSION

http://dx.doi.org/10.1016/j.retrec.2015.07.005

PUBLISHER

(c) Elsevier

VERSION

AM (Accepted Manuscript)

\section{PUBLISHER STATEMENT}

This work is made available according to the conditions of the Creative Commons Attribution-NonCommercialNoDerivatives 4.0 International (CC BY-NC-ND 4.0) licence. Full details of this licence are available at: https://creativecommons.org/licenses/by-nc-nd/4.0/

\section{LICENCE}

CC BY-NC-ND 4.0

\section{REPOSITORY RECORD}

Veeneman, Wijnand, Katrin Augustin, Marcus Enoch, Bruno Faivre d'Arcier, Silvia Malpezzi, and Niek Wijmenga. 2015. "Austerity in Public Transport in Europe: The Influence of Governance". Loughborough University. https://hdl.handle.net/2134/20084. 


\title{
AUSTERI TY IN PUBLIC TRANSPORT IN EUROPE: THE I NFLUENCE OF GOVERNANCE
}

Authors: Wijnand Veeneman ${ }^{1}$, Katrin Augustin ${ }^{2}$, Marcus Enoch $^{3}$, Bruno Faivre d'Arcier ${ }^{4}$, Silvia Malpezzi ${ }^{5}$, Niek Wijmenga ${ }^{6}$

\begin{abstract}
The financial crisis has put pressure on government budgets across Europe. The expectation is that this also has affected public transport budgets in metropolitan areas. This article looks at five cases of metropolitan public transport to see to what extent this is the case. Multi-level governance and fiscal federalism explain the rather surprising outcome.

This article is aimed to be a first step into a better understanding of the effect of governance in public transport in a broad sense. It develops the understanding of how the organizational context influences those funding decisions and the related outcome in terms of public transport services provided and passengers transported. The article shows that the effect of budget pressure was varied over the five cases depending on governance in those cases and overall can be characterized as limited. Funding and supply generally kept growing, despite the pressure put on budgets by the financial crisis.
\end{abstract}

\section{Introduction: the financial crisis and metropolitan public transport}

Public transport is a strong policy instrument in the hand of local and regional policymakers to provide a more sustainable alternative to transport by car. It provides a tool that can be applied in environmental policies, urban development, mobility management, and social inclusion policies. It can support a great number of the public values (Veeneman, Van de Velde and Lutje Schipholt, 2006) related to these policy fields: from a healthier environment to economic development, from fighting global warming to local upgrading, from reducing congestion to increasing participation. These are the values public entities want to secure when they develop their public transport related policy.

Over the course of the last decades, these various public values became key reasons for regional and local authorities to provide financial support in the form of subsidies for the provision of public transport services. As public funding has become a substantial part of the funding of public transport, public decision-making had a growing role in the sector.

In 2008, the European economy experienced the great recession (see also Pearce, 2012). As a result, public revenue from taxes was reduced, scrutiny on deficits increased and public budgets put under pressure. We expect the effect on public transport funding to be different under different governance and financing structures and arrangements; the institutional context under which influence the public decisions on public transport are made.

\footnotetext{
${ }^{1}$ Corresponding author, Delft University of Technology, Delft, The Netherlands, W.W.Veeneman@TUDelft.nl

${ }^{2}$ KCW, Berlin, Germany

${ }^{3}$ Loughborough University, Loughborough, United Kingdom

${ }^{4}$ L'Université de Lyon, Lyon, France

${ }^{5}$ Reply, Milano, Italy

${ }^{6}$ Delft University of Technology, Delft, The Netherlands
} 
To evaluate the effect, the paper looks a number of governance aspects that are expected to have an effect on the way in which budget pressure has an effect on the actual funding of public transport. The paper presents these as hypotheses around the tax base, fragmentation of decision-making, the existence of task organizations and the existence of long-term commitments, generally seen in tendered concessions to commercial operators. The paper also looks at the effect of the changes in funding on the use of public transport.

This article is a first analysis of the relation between those variables: governance and financing of public transport and the pressure on budgets of public transport following the financial crisis. We have selected five cases for a first analysis of the possible relations mentioned above. We want to position this article as a first step towards understanding the relation between governance of public transport and the way in which a pressure on funding is dealt with.

\section{Approach: inductive case exploration}

As a first inductive exploration this article looks at the relation between the pressure on public budgets, the governance of public transport and the effect on public transport services and usage. In that analysis we treat the governance as the system of decision-making with an output of budget decisions on public transport.

Williamson (2000) focuses on a set of contracts as the key base of governance. He also shows how institutions, where he focuses on the legal system, conditions the way contracts drive decision-making. This paper focuses on these contracts in public transport provision. Key institutions are the way the legal system distributes tasks over various layers of government and structures financing of public transport. For those, contracts and key institutions, this paper will use the term public transport governance, or governance for short.

Our main question is:

How do different forms of public transport governance affect metropolitan public transport budget, service provision and usage, given a level of pressure on the budget?

In managing the financial crisis the national level of government played an important role in the five countries we have included in the selection. European budget regulation put pressure on the maximum budget

This introduces the need to analyze the role of different levels of government in setting the budget and goals for metropolitan public transport (see also Eyraud and Moreno Badia, 2013). So, for all cases this article presents a brief overview of the governance, with a focus on the roles of different levels of government. We structure the multi-level governance forms based on the perspective of Hooghe and Marks (2003), which allows us to understand the key dilemmas when decision-making power on related issues is spread over multiple governmental layers. In addition, we looked at the specific role of funding, and included the perspective on fiscal federalism (Oates, 2005).

To provide a first answer to that question, we carried out a set of initial case comparisons. We selected five cases with different governance structures. These case studies are found in five different countries, where national legislation sets different institutional conditions. In addition, we chose a regional focus, as this is the level of governance where design choices and funding choices for public transport in metropolitan areas are generally concentrated. The cases selected consisted of cities with 200.000 to 2.000.000 inhabitants and the administrative region responsible for the public transport in and around that city. We also selected cases in which the 
governance and funding of public transport were substantially different in terms of their multi-level governance and the sources of funding.

All cases are subject to the same European regulation (European parliament and Council of the European Union, 2007). We have selected cases in France, I taly,

Germany, The Netherlands and the United Kingdom. These countries have distinct national regulatory regimes and different governance of public transport on a regional level.

For the cases a number of variables was key for the period from the start of the crisis in 2008 until 2012. The cases looked at:

- A proxy for pressure on the budget on a national level;

- Governance structure and decision-making distribution over different levels of government;

- Funding sources for public transport;

- Development of the subsidy for public transport following the financial crisis;

- Development of the supply of services of public transport following the financial crisis;

- Development of the use of public transport in terms of trips or kilometers following the financial crisis.

It is important to understand that the last three elements of the data have the goal to illustrate the development per case, given the assumed budget pressure. Between the cases we compare the relation between that development and the governance and funding. This is essential; the cases show different ways to measure and operationalize the data types that we have selected, challenging the direct detailed comparability of that data between cases. However, the data illustrates the development in the case well, and that is how we will use that data.

To summarize, the paper looks at budget pressure as an independent variable, various aspects of the governance as intermediate variables and the subsidies for, output by, and use of public transport as dependent variables.

This research is a first step in understanding the relation between governance and funding on the one hand and the effect of budget pressure under austerity on the other. We explore the relation as posed in four hypotheses in the cases. The research aims to developing more specific pointers for a future (more quantitative) analysis of the relation between public transport governance and the way in which austerity measures work out. Such a research will need a first evaluation of possible relevant variables to analyze in the survey. It is this step that this article provides.

\section{Theoretical framework:} multi-level governance and fiscal federalism

In administrative science, a debate has been going on for decades on the best governmental level in which decision-making should be organized. In transport the theoretical debate was more focused, as the action space of many travellers is limited to metropolitan region, leading to the view that this metropolitan level is the right level to deal with the integrated decision-making on transport policies (Witbreuk, 2000). In addition, network design issues are most prominent on those locations where many different (levels of) networks meet, at key hubs in metropolitan areas (Nes, 2002). As a result, putting the decision-making on a metropolitan level seems to make sense in the world of public transport. Obviously, some networks are stretching beyond the metropolitan area. Networks of railway and also bus services can have national or even international characteristics. And in the field of public transport, these different levels of services combined 
improve their value through service coordination (e.g. time-tables, operating hours), system coordination (e.g. platform height, safety systems, loading and track gauge, catenary voltage), and market coordination (e.g. cabotage rights, market regulation) across these levels of service. Especially in railways, technical system coordination is essential, as the moving vehicle has many dependencies with the localized infrastructure.

Consequently, there is value in coordinated decision-making on public transport on specific aspects on a national level or even a supra-national level. A sound example is the development of European Technical Specifications for Interoperability (TSI s) for the purpose of realizing technological system coordination across the national boundaries, including the development of ECTS as a uniform traffic control system. This all illustrates that decision-making on different aspects of public transport services makes more sense on different levels of government. A municipality deciding on track gauge is absurd, the European parliament deciding on a standardized timetable for services everywhere is as absurd.

However, the detailed optimal answer on how to distribute decision-making over different levels of government is not as straightforward. An empirical illustration of the conundrum is the governance of the Paris public transport system. Over time the transport authority STIF has been a national authority and a cooperation between departments and municipalities (Kapteijn et al., 2012). Different governments had different views on the role of the national government in the governance of the public transport system of île de France.

Also elsewhere there is much discussion on transport jurisdictions being too fragmented, demanding for further integration achieving economies of scale (O'Sullivan and Patel, 2004; Witbreuk, 1997). On the other hand, the point is made that there is too much high level control, asking for decentralization on the basis of subsidiarity (see Bermann, 1994; Oates, 2005). In his work Chisholm (1989) shows that different levels of government with high fragmentation can organize transport quite well, even without a single authority coordinating. Tsebelis (Tsebelis, 2000) shows how a spread of (veto) power in a more fragmented governance can affect the ability of the governance system to realized major changes, like in our case substantial budget cuts.

Hooghe and Marks (2001) give an excellent overview of the key dilemmas that exist in the cooperation of jurisdictions (cities, municipalities, provinces, departments, regions, states, countries, with an dedicated governance structure) on various levels and their role in the decision-making process. They show that there is no singular answer on whether jurisdictions should be designed around communities or should be designed around policy problems. Community based allows for coordination between problems (e.g. linking public transport policy to spatial policy), (problem and) task-oriented jurisdictions can deal focused with a specific problem, (e.g. German and Swiss Verkehrsverbünde).

So, when we accept the fact that governance could influence the way in which austerity measures are taken, the way that jurisdictions and their responsibilities on public transport are set up can play an important role. Different problems (even in the field of public transport) can ask for different jurisdictions to deal with them. Optimizing a specific jurisdiction for each design problem (e.g. ticketing, pricing, routing, time-tabling, infrastructure standards, vehicle standards, etc.) leads to extreme fragmentation. The key answer to this dilemma is found in hybrid forms, like ad-hoc or problem-and-task-oriented jurisdictions of cooperating communitybased jurisdictions, like current in many metropolitan transport authorities. The governance issue becomes more complex when decision-making on various problems over different levels is separated from funding issues. In his work on fiscal 
federalism, Oates (2005, p.353) shows key mechanisms that hinder an efficient realization of public values (where he focuses on public "outputs") when funding and decision-making are on different governmental levels. He cites De Tocqueville on the focus put on uniformity from the higher governance level, in a reality of variety in the lower levels. He also points at the incentives that exist for lower levels to overstate their needs, when funding is coming from a higher level. Veeneman (2002) recognized both in metropolitan public transport funding.

Oates adds further mechanisms like the incentive to centralize (including funding) based on individual gains of those directly involved, rather than based on seeking the right level for problem solving and decision-making. Also, information asymmetries and strategic use of information make optimizing governance over different levels of government far more complex.

In our article we want to consider whether the governance and funding structure in the cases have an influence on the way in which the pressure on funding is translated into the amount of money available for public transport, the supply of services and eventually patronage (see also Sørensen and Longva, 2011). We assume that the crisis has put pressure on public budgets, primarily on a national level. This assumption is coming from the fact that European budget rules demanded a maximum 3 percent of budget deficit on that level. With that in place, reducing income as a result of a poor economy will have a pressure on reducing expenditure, in a broad sense.

Based on the theory discussed above, this paper formulates four hypotheses for the cases to explore. Our first hypothesis relates to autonomy over tax revenues in a layered governance model. The hypothesis is that

A local tax base will reduce the effect of the budget pressure on the real expenditure on public transport, leading to limited effects on supply of services and patronage.

This could be even stronger when an earmarked tax is in place. It could be weaker when local taxes are related to economic development, like property tax and employment related tax. The effect would be depending on the sensitivity of that tax to economic activity; a poor local and regional economy could also hurt the local economy, and consequently tax revenue. We will have a look at to what extent funding is generated regionally, either in the form of subsidies or in fare box revenues.

A second hypothesis focuses on the effectiveness of decision-making in mono-lateral situations versus multi-lateral situations. The hypothesis is that

Fragmentation in governance on a metropolitan level will limit the effect of budget pressure on subsidies on public transport.

When no metropolitan jurisdiction exists, national budget pressure could trickle down slowly to all the different municipalities in a metropolitan area. When a metropolitan council exists, consisting of cooperating local jurisdictions, the decision-making can be slower, as interests between the local jurisdictions might conflict and negotiations will have to take place to come to decision-making on budgets. When a metropolitan or regional jurisdiction exists, the (supposed) national pressure could have direct effect and decision-making and could be swift. Obviously, it is also depending on the control the national government has on the funding of the jurisdictions in the region, as mentioned in the first hypothesis.

A third hypothesis focuses on organizational boundaries between the political and administrative entities and the task organizations that carry out public transport related policies. The hypothesis is that 
In jurisdictions based on communities budget pressure is

administratively easier to translate into reduction of the real

expenditure, than in jurisdictions based on problem-and-task oriented

organizations.

J urisdictions are generally community based: municipalities, provinces, departments, states, nations. When the jurisdiction on public transport is residing fully within such an entity, implementation of budget cuts can be straightforward. However, many metropolitan areas have problem-and-task-oriented jurisdictions for public transport. For example, municipalities have together set up a public transport authority. The jurisdiction of the authority is problem-and-task-oriented (only public transport) and spans various community-based jurisdictions (the municipalities). In such a case, an organizational barrier has to be taken between the decision-making entity (the municipalities) to the executing entity (the authority). That barrier can contain limitations for a swift reduction of the budget for public transport.

A fourth hypothesis focuses on the contract between the authority and the operator. The hypothesis is that

A regulatory regime with competitive tendering to private operators will dampen the effect of budget pressure as there are long-term concessions in place that limit the ability to reduce spending. The direct intervention in the budgets of publicly owned operators is expected to be more straightforward. The role of subsidies for free market operators is generally limited.

Flexibility in long-term competitively tendered out contracts with private operators is expected to be limited. The private operator has built its business case on the expectation of a certain level of turnover during the term of the concession. In addition, we see that the procurement of busses often is aligned with the term of the concession, as might be contracts with staff. All this focuses changes around the transfer of the concessions. However, this limits flexibility mostly when set of contracts is limited. With many smaller competitively tendered out contracts (either shorter or less services), changes can still be more gradual. It is expected that longterm direct-award contracts with public operators need and should contain more clauses for changing the service levels and related funding when needed, leading to more flexibility and easier reduction of funding, service levels and eventual probably patronage.

On the basis of the information we have available in the cases, the next section will evaluate the relevant variables in the cases and look at the hypotheses.

\section{The empirical data from the cases: governance and funding of public transport}

\subsection{Introduction}

First of all we have established a proxy for the budget pressure in the different cases.

We looked at tax revenues as the main driver of budget pressure. As secondary indicators of how that pressure affected funding for public transport, we looked at the development of general expenditure and specific expenditure on transport (GF0405 according to the Classification of Functions of Government) of all levels of government from 2005 until 2013 in the databases of Eurostat. The result of that analysis shows that the first assumption, that the financial crisis has put strains on 
the budget of governments, needs substantial reconsidering, at least for transport related spending.

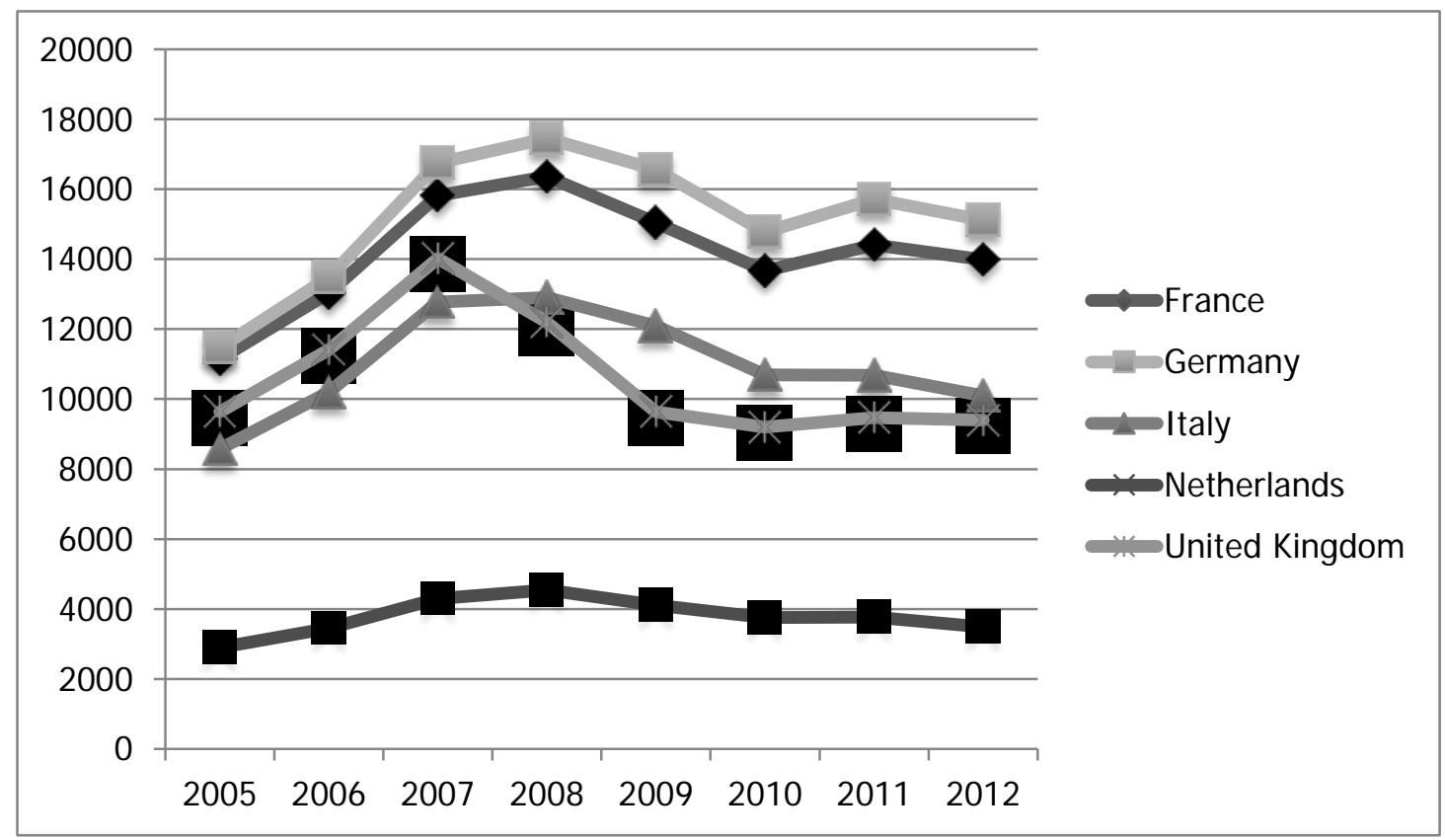

Figure 1 Tax revenues in millions of Euros corrected for inflation to 2005 (OESD, 2014)

Figure 1 shows tax revenues went down from 2008 in all five countries, most sharply in Italy and the United Kingdom (OECD, 2014). As revenue goes down, expectation is that the pressure on budget grows. We see an effect on the total expenditures, on all governmental levels we see the strongest decline in the United Kingdom and Italy and less so in Germany, France and the Netherlands from 2008 to 2012 (Eurostat, 2014). Expenditure on transport follows the same pattern, with Italy having the strongest decline, far more than the United Kingdom. France and the Netherlands show a small decline in transport related expenditure since 2008 through 2012, with Germany picking up spending on transport already in 2012. Governments in our five countries are bringing in less money to spend. Budget pressure is there, but the direct effect on expenditure and transport related expenditure is less strong on the five countries.

Consequently, if tax revenue is a suitable proxy for the budget pressure on the spending on regional public transport, all cases have experienced the pressure with the cases in Italy and the United Kingdom have experienced the strongest pressure. However, in spending already we see a dampening effect, which could be related to the position of the national government towards austerity measures. The strongest pressure was in 2008, 2009 and 2010. In our cases we want to see the development over time of three elements: funding for public transport, supply of public transport and use of public transport. Not all cases provide comparable information. However, we do not consider the data on those elements per se, however the development of funding, supply and use, given a expected budget pressure and a specific governance and funding system.

\subsection{Rhein-Main-Verkehrsverbund, Frankfurt, Germany}

Frankfurt is situated in the Bundesland (state) Hesse. The city itself has around 250,000 inhabitants (Frankfurt am Main, 2014), the region around 6 million (Pütz, 2012). The governance and funding is typical of the German Verkehrsverbund. 
Multiple local jurisdictions are represented in the problem-and-task-oriented governance structure of the Rhein-Main-Verkehrsverbund (RMV). The Bundesland (state) Hesse, 11 cities, including Frankfurt and 15 regions participate in the RMV and are represented in its board (RMV, 2014a).

Services are developed together with local and regional authorities. The RMV competitively tenders out the public transport operations. Contracts run around 7 years and the region has around 40 concessions for bus transport and around 28 for rail transport. The jurisdictions in the RMV all have their own tax base and contribute to the RMV and directly to the public transport in their own jurisdiction.

Public transport governance is not fragmented, with the existence of a single governing problem-and-task-oriented organization with representatives of all community-oriented jurisdictions. The RMV is the designated decision-making jurisdiction. Funding is coming from a local tax base, but taxes are not earmarked for public transport.

\begin{tabular}{|l|l|l|}
\hline Hypothesis & Expected effect & Explanation \\
\hline 1 & $\begin{array}{l}\text { Low effect of } \\
\text { budget pressure }\end{array}$ & Local tax base reduces the budget pressure \\
\hline 2 & $\begin{array}{l}\text { Medium effect of } \\
\text { budget pressure }\end{array}$ & $\begin{array}{l}\text { The public authority is not concentrated and not } \\
\text { fragmented over various organizations, however, } \\
\text { multiple funding streams exist and different } \\
\text { jurisdictions are involved in the governance of the } \\
\text { authority. }\end{array}$ \\
\hline 3 & $\begin{array}{l}\text { Low effect of } \\
\text { budget pressure }\end{array}$ & Problem-and-task-oriented organization in the RMV \\
\hline 4 & $\begin{array}{l}\text { Medium effect of } \\
\text { budget pressure }\end{array}$ & $\begin{array}{l}\text { Tendering of public transport operations leads to } \\
\text { long-term contract that are not easily reduced. } \\
\text { However, in this case many smaller concessions and } \\
\text { contracts would provide more flexibility }\end{array}$ \\
\hline \multicolumn{2}{|c|}{ Table 1 Governance and funding hypotheses in the Frankfurt case }
\end{tabular}

Table 1 shows that on all our hypotheses the Frankfurt case has the governance and funding characteristics to fend off budget pressure. Consequently, the expectation is that the effect of the budget pressure is limited. In addition, our proxy already showed that the budget pressure in Germany seems to be limited. So, in total we expect a limited effect of budget pressure in the Frankfurt case.

\begin{tabular}{|r|r|r|r|r|r|r|}
\hline Year & \multicolumn{1}{|c|}{2007} & \multicolumn{1}{|c|}{2008} & \multicolumn{1}{|c|}{2009} & \multicolumn{1}{c|}{2010} & \multicolumn{1}{c|}{2011} & \multicolumn{1}{c|}{2012} \\
\hline Subsidy $^{7}$ & 455 & 441 & 451 & 463 & 465 & 467 \\
\hline Bus kilometers $^{8}$ & n.a. & n.a. & n.a. & 24.3 & 24.4 & 24.0 \\
\hline Lines $^{8}$ & 56 & 57 & 57 & 60 & 59 & 63 \\
\hline Lines length $^{8}$ & 511 & 521 & 528 & 531 & 529 & 567 \\
\hline Traveller kilometers & 160.1 & 184.7 & 194.5 & 196.5 & 198.7 & 196.8 \\
\hline Traveller trips & 48.3 & 49.7 & 52.5 & 53.2 & 53.6 & 53.3 \\
\hline Farebox revenues & n.a. & n.a. & n.a. & 165 & 176 & 161 \\
\hline
\end{tabular}

Table 2 The effect variables in the Frankfurt case ${ }^{9}$ (sources: Hessen, 2014; RMV, 2014b)

\footnotetext{
${ }^{7}$ Data limited to the contribution of Bundesland Hessen

${ }^{8}$ Data limited to the city of Frankfurt

${ }^{9}$ For all tables: subsidies are in millions of euros corrected for inflation to 1-1-2005, line lengths are in kilometers, bus and traveller kilometers in millions per annum, traveller trips are per annum, and fare box revenues are in millions per annum corrected for inflation to 1-1-2005. All financial data is in money of the day. The colors distinguish between indicators of funding (white), supply (light grey) and use (dark gray) of public transport services.
} 
Table 2 indeed shows a limited effect: if budget pressure was apparent in this case, is did no trickle into public transport. Since 2008 the amount of funding that the state of Hessen has made available for public transport operation has been steadily rising. The supply of services is growing in the region, both in number of public transport lines and the length of the lines. In addition, patronage is also up, both in number of traveller kilometers as well as in the number of trips. The data shows that in the later years farebox revenues are varying without a clear trend.

\subsection{Syndicat Mixte des Transports du Rhône et l'agglomération Lyonnaise, Lyon, France}

Lyon is situated in the southeast of France and the capital of the Rhône department and the region Rhône-Alpes (Sytral, 2013). The city itself has around 500,000 inhabitants, the region around 2.1 million. The governance and funding is concentrated in the Syndicat Mixte des Transports du Rhône et l'agglomération Lyonnaise (SYTRAL). In total 65 municipal jurisdictions (all 59 municipalities in the Grande Lyon region and six municipalities outside Grande Lyon) are represented in the board of SYTRAL. SYTRALs main task is public transport provision, and as such represents a problem-and-task-oriented governance structure.

Services are developed together with operator and local and regional authorities. SYTRAL competitively tenders out the public transport operations in one big concession (new contracts in 2005 and 2011), a key difference with the RMV. Currently, the operator is Keolis Lyon. The contract runs 6 years. The versement transport (a company tax, earmarked for public transport) contributes about 60 percent of the total funding for subsidy. Revenue of that company tax has been growing almost 17 percent (from $230 €$ million in 2007 to $268 €$ million in 2013), well above the 7.6 percent inflation in that period. The remainder of the funding comes mostly from the municipalities and smaller other sources. These contributions have also been growing. Also, SYTRAL receives a limited state investment grant. In our perspective, relative to the other cases public transport governance is definitely not fragmented, with the set up of a single governing organization with a problem-and-task-oriented. Also here, governance over the different levels is simplified because of the board with representatives of all community-oriented jurisdictions. SYTRAL controls the full funding. As stated, funding is coming from a local tax base, a lot of which is earmarked for public transport; the versement transport. Despite possible economic problems and their effect on the companies contributing to the tax, the revenue of the tax has been growing.

\begin{tabular}{|l|l|l|}
\hline Hypothesis & Expected effect & Explanation \\
\hline 1 & $\begin{array}{l}\text { Low effect of } \\
\text { budget pressure }\end{array}$ & Local tax base reduces the budget pressure \\
\hline 2 & $\begin{array}{l}\text { High effect of } \\
\text { budget pressure }\end{array}$ & $\begin{array}{l}\text { A single authority with a single integrated funding } \\
\text { stream }\end{array}$ \\
\hline 3 & $\begin{array}{l}\text { Low effect of } \\
\text { budget pressure }\end{array}$ & $\begin{array}{l}\text { Problem-and-task-oriented organization in the } \\
\text { SYTRAL }\end{array}$ \\
\hline 4 & $\begin{array}{l}\text { Mixed effect of } \\
\text { budget pressure }\end{array}$ & $\begin{array}{l}\text { Tendering of public transport operations leads to } \\
\text { long-term contract that are not easily reduced. } \\
\text { However, in this case one big contract was tendered } \\
\text { twice, allowing for possible reductions. }\end{array}$ \\
\hline
\end{tabular}

Table 3 Governance and funding hypotheses in the Lyon case 
Table 3 shows that on the Lyon case has the governance and funding characteristics to fend off budget pressure, there is a local tax base and SYTRAL is a problem-andtask oriented organization, limiting the possibilities for moving funding away from public transport by shifting between items in a single budget. Consequently, the expectation is that the effect of the budget pressure is limited. In addition, our proxy already showed that the budget pressure in France seems to be limited. So, in total we expect a limited effect of budget pressure in the Lyon case.

\begin{tabular}{|r|r|r|r|r|r|r|}
\hline Year & \multicolumn{1}{|c|}{2007} & \multicolumn{1}{|c|}{2008} & 2009 & 2010 & \multicolumn{1}{|c|}{2011} & \multicolumn{1}{c|}{2012} \\
\hline Subsidy & 139 & 139 & 143 & 145 & 157 & 157 \\
\hline Bus kilometers & 49 & 49 & 47 & 49 & 53 & 56 \\
\hline Lines length & 1,249 & 1,255 & 1,232 & 1,290 & 1,351 & 2,947 \\
\hline Traveller trips & 366 & 388 & 395 & 378 & 400 & 423 \\
\hline Farebox revenues & 140 & 146 & 146 & 150 & 157 & 164 \\
\hline
\end{tabular}

Table 4 The effect variables in the Lyon case ${ }^{8}$ (Source: Sytral, 2013)

Table 4 indeed shows that the subsidy has been growing over the entire period, with no effect of the assumed budget pressure. Since 2007, subsidies have been growing, with a large increase in 2011 . The supply of services is growing in the region, in terms of the length of the lines. In addition, patronage is also up, both in in the number of trips and in fare box revenues.

\subsection{Province and Municipality of Milan, Milan, I taly}

Milan is situated in the northwest of Italy, in the Lombardy (Malpezzi, 2014). The municipality of Milan is the governmental body responsible for public transport in the Milan urban area. The municipality has around 1.3 million inhabitants. The municipality's mobility agency (AMAT) has tendered out the service provision in the urban area to ATM S.p.A. and is retaining the revenues themselves. AMAT was set up in 2009.

The province of Milan is responsible for public transport around the city, presumably bus transport. The province ${ }^{10}$ government tenders out its own services in six concessions to six different operators (Autoguidovie, Brianza, CAL, Movibus, NET, PMT). Train services are under the control of other regional and national governments.

The national government funds most of the public transport subsidies, about 80 percent. It provides a subsidy to the regions, which in turn provide subsidies to the municipalities. Both the national and regional government are pushing for a substantial reduction in budgets for public transport.

\begin{tabular}{|l|l|l|}
\hline Hypothesis & Expected effect & Explanation \\
\hline 1 & $\begin{array}{l}\text { High effect of } \\
\text { budget pressure }\end{array}$ & $\begin{array}{l}\text { Most of the funding for subsidies is coming from the } \\
\text { national government }\end{array}$ \\
\hline 2 & $\begin{array}{l}\text { Medium effect of } \\
\text { budget pressure }\end{array}$ & $\begin{array}{l}\text { Two authorities in the area, with different roles. The } \\
\text { need for shared decision-making is limited }\end{array}$ \\
\hline 3 & $\begin{array}{l}\text { Medium effect of } \\
\text { budget pressure }\end{array}$ & $\begin{array}{l}\text { AMAT is since } 2009 \text { the transport authority for the } \\
\text { municipality, no transport authority for the province }\end{array}$ \\
\hline 4 & $\begin{array}{l}\text { High effect of } \\
\text { budget pressure }\end{array}$ & $\begin{array}{l}\text { Tendering of public transport operations leads to } \\
\text { long-term contract that are not easily reduced. }\end{array}$ \\
\hline
\end{tabular}
Table 5 governance and funding hypotheses in the Milan case

\footnotetext{
${ }^{10}$ The province recently changed to a metropolitan council.
} 
The table above shows that we expect a relatively high effect of budget pressure on public transport, when comparing Milan to the other cases. Especially, the fact that the national government is providing most of the funding for the subsidies in public transport is only also found in the Amsterdam case. Fragmentation is limited with two separate governmental layers (province and municipality), but both have distinct tasks with limited dependencies. Fragmentation is somewhat higher because of AMAT, the transport authority, put at arms length of the municipality.

The municipality has been tendering of the services only since 2010. That means that the first tendering would have allowed for substantial budget cuts. However, after the first tendering, changes in budget under an existing contract will be less. As the pressure was highest in 2009, we expect a high effect of the budget pressure.

\begin{tabular}{|r|r|r|r|r|r|r|}
\hline Year & \multicolumn{1}{|c|}{2007} & \multicolumn{1}{|c|}{2008} & \multicolumn{1}{|c|}{2009} & \multicolumn{1}{|c|}{2010} & \multicolumn{1}{c|}{2011} & \multicolumn{1}{c|}{2012} \\
\hline Subsidy & 280 & 275 & 290 & 304 & 280 & 273 \\
\hline Vehicle kilometers & n.a. & n.a. & n.a. & 79 & 81 & 83 \\
\hline Lines & 127 & 127 & 103 & 103 & 116 & 123 \\
\hline Lines length & 1400 & 1441 & 1096 & 1096 & 1214 & 1226 \\
\hline Traveller trips & 653 & 696 & 702 & 702 & 699 & 698 \\
\hline Farebox revenues & 253 & 272 & 285 & 278 & 263 & 273 \\
\hline
\end{tabular}

Table 6 shows that the subsidies for public transport were growing until 2010, after which they were reduced again. The year 2009 saw a substantial reduction of the services, which was followed by a growth again in 2011 . Since 2008, patronage is very stable and does not seem to be affected by these major changes in subsidies and service levels. The farebox revenues are slightly more volatile due to price changes.

\subsection{Stadsregio Amsterdam, Amsterdam, The Netherlands}

Amsterdam is situated in the west of the Netherlands and the capital of the Netherlands. The city itself has about 700,000 inhabitants. The region has around 1.5 million inhabitants (CBS, 2014). The governance and funding is concentrated in the Stadsregio Amsterdam (SRA). It is a cooperative entity between 16 municipal jurisdictions, which are represented in the board. SRA has a wider set of tasks beyond public transport, including infrastructure, spatial planning, youth and economic policy (SRA, 2014). It has a wider focus in terms of problem-and-task orientation, than SYTRAL and RMV.

Services are developed together with operator. SRA competitively tenders out the public transport operations in three more peripheral concessions to private operators. The central concession is direct-awarded to the municipal transport operator of the city of Amsterdam GVB. This concession is important, it takes around 80 percent of the total subsidy.

Funding for public transport is almost entirely provided by the national government in a lump sum dotation for infrastructure and public transport operational subsidies: the Brede Doeluitkering (BDU). The development of the BDU (Ministerie van Infrastructuur en Milieu, 2014) showed how reduced tax revenue was translated to reduced funding for public transport in the Netherlands. In 2007 BDU funding for the whole country was $1,9 €$ billion growing to 2,0€ billion in 2010 staying at that level until 2013. From 2007 to 2013 inflation was around 13 percent. In addition, the

\footnotetext{
${ }^{11}$ Data limited to ATM
} 
receivers of those funds also received substantially additional task to carry out with that funding. All in all, a clear budget cut, strongest since 2010.

In our perspective, relative to the other cases, public transport governance is not fragmented, with the set up of a single governing problem-and-task-oriented organization with representatives of all municipal jurisdictions. Like SYTRAL, SRA controls the full funding stream. However, funding is coming from the national government. That is earmarked for a broader set of tasks. Over the last years, the national government has been reducing the funding on a national level and has been adding tasks. The budget pressure on the regional level is clear, even though our proxy for the Netherlands as a whole showed relatively low pressure.

\begin{tabular}{|l|l|l|}
\hline Hypothesis & Expected effect & Explanation \\
\hline 1 & $\begin{array}{l}\text { High effect of } \\
\text { budget pressure }\end{array}$ & $\begin{array}{l}\text { National tax base allows for national pressure on the } \\
\text { regional budgets } \\
\text { bugh effect of }\end{array}$ \\
\hline 2 & $\begin{array}{l}\text { A single authority with a broader perspective than } \\
\text { bublic transport }\end{array}$ \\
\hline 3 & $\begin{array}{l}\text { budget pressure } \\
\text { budget pressure }\end{array}$ & $\begin{array}{l}\text { SRA has a problem-and-task orientation, but at the } \\
\text { same time SRA is responsible for wider set of tasks. } \\
\text { This could limit the ability to fend off pressure to the } \\
\text { public transport budget, because of pressure on } \\
\text { other policy fields within SRA. }\end{array}$ \\
\hline 4 & $\begin{array}{l}\text { The main contract is not competitively tendered, } \\
\text { which should allow for flexibility in funding and } \\
\text { services. However, three other concessions were } \\
\text { competitively tendered to private operators for long } \\
\text { periods (8 years) with possible extensions of 2 more } \\
\text { years. This could hinder flexibility. }\end{array}$ \\
\hline
\end{tabular}

Table 7 Governance and funding hypotheses in the Amsterdam case

Table 7 shows that SRA in the Amsterdam case has the governance and funding characteristics not as geared to fend off budget pressure as in the other cases. Consequently, the expectation is that the effect of the budget pressure is higher. In addition, our proxy already showed that the budget pressure in the Netherlands is higher and the real funding (from national to regional) has been under pressure. So, in total we expect a stronger effect of budget pressure in the Amsterdam case, than in the other cases.

\begin{tabular}{|r|r|r|r|r|r|r|}
\hline Year & \multicolumn{1}{|c|}{2007} & \multicolumn{1}{|c|}{2008} & \multicolumn{1}{|c|}{2009} & \multicolumn{1}{c|}{2010} & \multicolumn{1}{c|}{2011} & \multicolumn{1}{c|}{2012} \\
\hline Subsidy & 294 & 303 & 314 & 328 & 307 & 327 \\
\hline Vehicle hours $^{12}$ & 1,618 & 1,636 & 1,662 & 1,699 & 1,706 & 1,620 \\
\hline Vehicle kilometers $^{12}$ & 35 & 36 & 37 & 38 & 37 & 35 \\
\hline Traveller kilometers $^{12}$ & 138.6 & 135.7 & 139.7 & 155.1 & 164.4 & 168.7 \\
\hline Traveller trips $^{12}$ & 209 & 213 & 219 & 200 & 204 & 206 \\
\hline Farebox revenues $^{12}$ & 146 & 148 & 156 & 171 & 186 & 201 \\
\hline
\end{tabular}

Table 8 The effect variables in the Amsterdam case 8 (sources: SRA, 2014; In 't Veld and Schepers, 2014; Bakker, Derriks and Savelberg, 2011; GVB, 2014)

Table 6 shows the effect of the budget pressure in the Netherlands. The expectation from the hypotheses is a high effect, because of the single authority, the directaward of the main contract and the national funding. The effect is indeed visible in

\footnotetext{
${ }^{12}$ Data limited to the main concession in the region, held by the GVB
} 
2011. Subsidy is going down around 5 percent in that year. At the same time, supply stays at the same level and use is going up. We also see a growth in revenues, which could be the effect of higher prices or reduced fare dodging. In that period a contactless ticketing system was introduced, with a new pricing structure and gating off of the metro. It is likely that this has triggered both effects.

\subsection{Transport for Greater Manchester, Manchester, United Kingdom}

Manchester is situated in the northwest of England, in the United Kingdom. The city has around 500.000 inhabitants. The region has a total of 2,685 million inhabitants (TfGM, 2014a). Transport for Greater Manchester (TfGM) is coordinating the public transport system in the region, next to a wider set of transport related tasks. TfGM has a governing board in the form of the Transport for Greater Management Committee, with 33 representatives from the 10 boroughs (districts) of the greater Manchester area.

The TfGM competitively tenders out a limited part of the bus services in the area. Most bus services, though, are developed and operated by private operators, the big three being Arriva, Stagecoach and First. The French public transport company RATP holds a ten-year concession operating and maintain the tram in the city, Metrolink. TfGM owns the system.

While in our other cases the transport authority initiates the delivery of the bus services (see Van de Velde, 1999) either through direct-award or competitively tendering services, TfGM can add services, after market initiative has taken its course. TfGM can fill possible gaps the private operators leave and spend $31 \mathrm{f}$ million (or $39 €$ million) in 2011 on that task by tendering out bus services. It also provides concessionary fares (reduced fares for vulnerable groups), which took up around $66 f$ million (or $83 €$ million) in that year. Also, it provides traveler information and investment support for infrastructure and accessible transport.

TfGM receives its funding from the ten councils of the boroughs in the Greater Manchester area through a levy (totaling around $190 \mathrm{f}$ or $230 €$ in 2011). The levy is general and not earmarked for public transport. In addition, the national Department of Transport is proving a rail grant to the region that is earmarked for tendering out of services on the Northern Rail ( $82 \mathrm{f}$ million or $103 €$ in 2011). It was part of national budget cuts.

In our perspective, relative to the other cases public transport governance is not fragmented, with the set up of a single governing organization with a problem-andtask-orientation on transport policy issues in the whole Greater Manchester area.

\begin{tabular}{|l|l|l|}
\hline Hypothesis & Expected effect & Explanation \\
\hline 1 & $\begin{array}{l}\text { Low effect of } \\
\text { budget pressure }\end{array}$ & Local tax base reduces the budget pressure \\
\hline 2 & $\begin{array}{l}\text { High effect of } \\
\text { budget pressure }\end{array}$ & $\begin{array}{l}\text { A single authority with a single integrated funding } \\
\text { stream }\end{array}$ \\
\hline 3 & $\begin{array}{l}\text { Low effect of } \\
\text { budget pressure }\end{array}$ & $\begin{array}{l}\text { TfGM has a problem-and-task-oriented organization, } \\
\text { slightly broader than public transport. }\end{array}$ \\
\hline
\end{tabular}




\begin{tabular}{|l|l|l|}
\hline 4 & $\begin{array}{l}\text { Low effect of } \\
\text { budget pressure }\end{array}$ & $\begin{array}{l}\text { The largely open market means that reduction of } \\
\text { government expenditure could have a limited effect } \\
\text { on overall supply. The tram is tendered out in a 10- } \\
\text { year concession, also limiting the effect of pressure. } \\
\text { It is running without subsidy. Part of the bus services } \\
\text { is tendered, but that is a limited percentage of the } \\
\text { market. }\end{array}$ \\
\hline
\end{tabular}

Table 9 Governance and funding hypotheses in the Manchester case

Our proxy showed earlier that the budget pressure on transport in general was relatively high in the United Kingdom; government expenditure on transport went down substantially since 2008. Table 9 shows the expectation of a relatively low effect of the budget pressure. TfGM is an organization with a specific problem-andtask orientation. This could hinder shifting money around between departments and as such limit the possibilities. In addition, the local tax base could limit the effect of the budget pressure from the national government, as local money streams counter it. Moreover, the concession for the tram, under government initiative, is running without subsidy. This means that even with reduced government spending, supply could stay at the same level, reducing the effect of budget pressure. Finally, even if government spends less money, the largely open market reduces the dependency of supply on government funding.

\begin{tabular}{|r|r|r|r|r|r|r|}
\hline Year & $2007 / 8$ & $2008 / 9$ & $2009 / 10$ & $2010 / 11$ & $2011 / 12$ & $2012 / 13$ \\
\hline Subsidy $^{13}$ & 135 & 134 & 121 & 110 & 105 & 113 \\
\hline Lines $^{13}$ & 3 & 3 & 3 & 3 & 4 & 6 \\
\hline Lines length $^{13}$ & 464 & 457 & 458 & 461 & 460 & 483 \\
\hline Traveller kilometers $^{13}$ & 210.0 & 220.7 & 206.1 & 200.8 & 228.4 & 261.7 \\
\hline Traveller trips $^{13}$ & 266.9 & 268.6 & 275.8 & 269.3 & 265.4 & 265.5 \\
\hline Farebox revenues $^{13}$ & 37 & 33 & 28 & 25 & 28 & 35 \\
\hline
\end{tabular}

Table 10 The effect variables in the Manchester case ${ }^{8}$ (TfGM, 2014b; DoT, 2014)

Table 10 suggests that budget pressure indeed lead to reduced funding for public transport by 2010. However, this is the effect of the currency conversion to euros. Only after 2012 we see a significant reduction in $\mathrm{f}$ because of the fact that the rail grant from the national government went down by 35 percent. On a regional level though, funding stays at the same level. For the farebox revenue, the table suggests a dip in 2009 and 2010. As this is also a currency effect, the real trend in pounds was growth since 2009 .

As funding grows also supply of services grows. For all types of public transport the line length shows a limited growth. And for the tram the number of lines grows. The use of public transport shows a reduction in trips from 2009, but a growth of the kilometers travelled on the tram since 2012. Farebox revenues go up after dipping in 2009.

\section{Analysis of the cases}

A first major conclusion has to be that the cases show a limited effect of budget pressure on public transport, basically in all cases. First of all, transport expenditure on a national level stayed at a similar level in three of the five countries. Only in the

\footnotetext{
${ }^{13}$ Data limited to the Manchester tram system.
} 
United Kingdom and I taly, spending on transport in general went down substantially. In Manchester we can see this in the reduction of the railway grant.

The case in which the pressure seems to be most directly translated into reduced funding is in the Netherlands, the Amsterdam case and in Italy, the Milan case. The specific aspect in these cases is that the regions have no local tax base used for public transport, different from the other cases. The national funding for public transport went down substantially, leading to a dip in government subsidy to public transport in both regions. Growing fare box revenues from passengers have counterbalanced this somewhat in Amsterdam, but not in Milan. In Amsterdam, the growing revenue was the effect of further distance traveled and a new ticketing system, reducing fare dodging. In 2012, however, the funding was back on its original growing trend line. In both Amsterdam and Milan, the effect on patronage was limited. In Lyon, France, the versement transport seems to limit the potential effect of budget pressure. Here, subsidy kept growing substantially over the years following the financial crisis of 2008.

Consequently, the effect on supply of services is mostly seen in the Milan case. Only after tendering supply levels went up again. In all different indices in all other cases, supply of services is essentially growing. The cases only show single years with a slight dip. Amsterdam 2012 can be seen as an exception with a substantial reduction of the vehicle hours in 2012.

In terms of use of public transport, the indicators show growth for Frankfurt and Lyon and little changes in Milan. In Manchester we see a reduction in trips since 2008, even though supply was not affected. This could be the effect of the crisis on the autonomous demand of public transport services. And in Amsterdam, with the direct effect of budget pressure, use is growing on traveller kilometers, despite a reduction in trips.

The cases provide a first illustration on how aspects of the governance structures in the regions can have an effect on the way in which austerity measures are taking form. Fragmentation seems to play a major role: the more separate the organization with a focus on public transport functions, the less straightforward it is to strongly reduce the funding as it is harder to shift money between budget elements. Fragmentation in decision-making can also come through local funding, where different jurisdictions all are contributing, like in Manchester. Decision-making on austerity measures can be slowed down on issues which jurisdiction will reap the benefit (by paying less or better services) and who will carry the burden (by paying more of having less services). The cases of Amsterdam and Milan showed how a singular money stream from higher levels of government seems to support a swift reduction in subsidies. This is also supported by the reduction of the UK railway grant to Manchester.

In terms of the governance structure between the authority and the operator, the cases show a wide variety. We have a free market (Manchester), direct-award (Amsterdam), competitive tendering in one big concession (Lyon), competitive tendering of separate urban and regional services (Milan), and competitive tendering in smaller concessions (Frankfurt). In our hypothesis this could provide the most barriers in the Lyon case, with the long-term contract blocking change. The least barriers to reduce funding would exist in the Amsterdam case, with a flexible contract and direct control over the municipal operator. In general, this is in line with our observations. 
When we combine the different hypotheses, on the one hand of the spectrum we see governance with many cooperating municipalities with their own tax base and a shared transport authority being less sensitive to the financial crisis then a regional government with a transport department being funded by national means.

The cases show little variety in terms of the community-oriented or problem-andtask-oriented jurisdictions. All cases show problem-and-task-oriented jurisdictions, with slight distinctions. RMV has a pure public transport orientation, SYTRAL and TfGM slightly broader and the SRA much broader. The latter seems to further support the easier reduction of funding.

Obviously, the cases do not provide enough data to decisively conclude the validity of our hypotheses. For example, what exact austerity measures were taken, has not been part of our analysis. Also, it would be valuable to see how effective actual fiscal stability measures can be. We see this article as a first inductive step. That said, the first and second hypothesis currently have the strongest explanatory power for the developments we see in the cases in terms of the response to budget pressure. A local and earmarked tax base and fragmented governance make the public transport budget less vulnerable. The availability of a substantial stream of local funding makes public transport less dependent on shifts in priorities in national funding streams. This is not a weakness of governance, just a different balance in national and local priorities reflected through their own funding stream. The fragmented governance could be seen as a weakness of governance, where multiple actors are less able to swiftly decide on (possibly needed) budget cuts for public transport than a single actor deciding on the funding.

The governance structure between authority and operator seems to have less of an influence. Operators that are government owned with direct-award contract proof to be less flexible than expected. Competitively tendered contracts provide a good basis for flexibility, as long as the concessions are not too big and the contract periods not to long. A free market situation is very flexible, but hardly depending on the government funding of public transport services.

\section{Conclusions}

Funding for public transport grows and diminishes. Obviously, part of that funding is dependent on the farebox revenue: when more people choose to travel, revenues grow. This is a very flexible coupling between the services provided and the revenues coming in. However, most public transport systems are substantially subsidized. Governments are deciding whether or not to spend public money on providing a public transport service.

That decision-making process is less straightforward than one might think. Public administration literature has shown many of the mechanisms that influence the way in which decisions on funding are made. They point at fragmentation in different levels of government and the way in which cooperation between these levels and between jurisdictions on a certain level are organized as key factors.

In this paper we looked at how these factors influenced the funding of public transport, in those moments that budget pressure is rising. In 2008 the financial crisis put pressure on the budgets of many European governments, which was expected to have also put pressure on the funding of public transport. In the cities in our study, we see only a limited effect of that budget pressure. Subsidies of public transport were not diminished substantially across the board and were often growing. The case that showed the most effect, Amsterdam, lacked characteristics that (from the theory) would allow for fending off that budget pressure: no (earmarked) local tax base, an relatively integrated organization on a 
metropolitan level governing on various policy areas, a direct-award contract to a publicly owned operator.

In our analysis we assert that the national funding of the Amsterdam region was the multi-level governance issue that played the most important role. It seems to be the key factor in the reduced funding for Amsterdam public transport.

Multi-level governance, and the horizontal and vertical fragmentation that it comes with, reduces flexibility. Negotiations on who will reap the benefits and who will carry the burden of a specific option under review take time in a decision-making process. That is not necessarily a negative thing. Public transport has the strongest position when it is developed in line with lengthy processes of spatial development. People choose for public transport as part of their broader decision in life: where to live and work (Currie and Rose, 2008). Stability of services in that context is of value and helps public transport being successful over the long run. Obviously, that argument is limited, as in the long-term reduction in demand should lead to reduction in supply.

Further research is needed to develop the understanding of governance in metropolitan public transport to understand how decision-making context influences the success of the public transport services it produces. This could start with extending the set of cases and including an analysis of the actual aursterity measure taken. This paper has shown that the variability in the included variables is high for the set of cases presented here. Adding cases could further develop the understanding of how governance influences funding decisions public transport. Key issue would be how multi-level governance would allow for an effective decisionmaking and funding of public transport. As the cases have shown, multi-level governance is the reality of metropolitan public transport.

\section{References}

Bakker, P, Derriks, H \& Savelberg, F (2011) Hoe groeit het regionaal openbaar vervoer?, Den Haag.

Bermann, GA (1994) "Taking subsidiarity seriously: Federalism in the European Community and the United States," in: Columbia Law Review, pp. 331-456.

CBS (2014) “NL CBS Statline," accessed May 1, 2014, from <http://statline.cbs. nl/>.

Chisholm, D (1989) Coordination without hierarchy, University of California Press, Berkeley.

Currie, G \& Rose, J (2008) "Growing patronage - Challenges and what has been found to work," in: Research in Transportation Economics, pp. 5-11.

DoT (2014) "Department of Transport; Light rail and tram statistics," accessed May 1, 2014, from <https://www.gov.uk/government/collections/light-rail-and-tramstatistics>.

European parliament \& Council of the European Eunion (2007) Regulation No $1370 / 2007$ of the European Union on public passenger transport services by rail and by road, European Union. 
Eurostat (2014) "COFOG Database," accessed February 1, 2014, from <http://epp.eurostat.ec.europa.eu/statistics_explained/index.php/Government expenditure_by_function_?_COFOG>.

Eyraud, L \& Moreno Badia, M (2013) 'Too Small to Fail? Subnational Spending Pressures in Europe," in: IMF Working Papers, p. 1.

Frankfurt am Main (2014) "Frankfurt am Main; Zahlen, Daten, Fakten," accessed May 1, 2014, from

<http://www.frankfurt.de/sixcms/detail.php?id=3877\&_ffmpar[_id_eltern]=281 $1>$.

GVB (2014) Jaarverslag GVB 2007 - 2012, Amsterdam.

Hessen (2014) Landeshaushaltplan 2007 - 2012, Frankfurt am Main, Germany, Hessen.

Hooghe, L \& Marks, G (2001) “Types of multi-level governance," in: European integration online papers (ElOP).

Hooghe, L \& Marks, G (2003) Unraveling the Central State, But How? Types of multilevel governance, Institute for Advanced Studies, Vienna.

Kapteijn, K, Erp, T van, Susteren, A van, Bijl, R van der \& Veeneman, W (2012) Public transport in the Randstad metropole in an international perspective; Potential and barriers for new public transport, Hoofddorp.

Malpezzi, S (2014) Governance of public transport in the Milan area, Milano.

Ministerie van Infrastructuur en Milieu (2014) “BDU Uitvoeringsregeling 2007 2012," accessed May 1, 2014, from

<http://wetten.overheid.nl/BWBR0018109/geldigheidsdatum_15-02-2014>.

Nes, R Van (2002) Design of multimodal transport networks; $A$ hierarchical approach, Delft University Press, Delft.

O'Sullivan, PJ \& Patel, T (2004) "Fragmentation in transport operations and the case for system integrity," in: Transport Policy, pp. 215-225.

Oates, W (2005) "Toward a second-generation theory of fiscal federalism," in: International tax and public finance, pp. 349-373.

OECD (2014) "OECD Database on GDP and tax revenue," , p. http://data.oecd.org/gdp/gross-domestic-product-gd, accessed December 10, 2014, from <http://data.oecd.org/gdp/gross-domestic-product-gdp.htm>.

Pearce, B (2012) "The state of air transport markets and the airline industry after the great recession," in: Journal of Air Transport Management, pp. 3-9.

Pütz, T (2012) Regionales Monitoring 2012; Daten und Karten zu den Europäischen Metropolregionen in Deutschland, Bonn. 
RMV (2014a) "RMV, Wir über uns," accessed February 1, 2014, from <http://www.rmv.de/de/Verschiedenes/Informationen_zum_RMV/Der_RMV/Wir _ueber_uns/>.

RMV (2014b) RMV Gesamtbericht 2008 - 2012, Hofheim am Taunus.

Sørensen, CH \& Longva, F (2011) "Increased coordination in public transport-which mechanisms are available?," in: Transport Policy, pp. 117-125.

SRA (2014) Jaarverslag en jaarrekening 2007 - 2012, Amsterdam.

Sytral (2013) Sytral Rapport Finacier Annuel 2007-2013, Lyon.

TfGM (2014a) "Transport for Greater manchester; Transport statistics," accessed May 1, 2014, from <http://www.gmtu.gov.uk/reports/transport2012.htm>.

TfGM (2014b) Transport for Greater Manchester Annual Report 2007 - 2012, Manchester.

Tsebelis, G (2000) "Veto Players and Institutional Analysis," in: Governance, pp. 441-474.

Veeneman, W (2002) Mind the Gap: Bridging theories and practice for the organisation of metropolitan public transport, Delft University Press, Delft.

Veeneman, W, Van de Velde, D \& Lutje Schipholt, L (2006) "The value of bus and train," in European Transport Conference (ETC), Association of European Transport.

In 't Veld, N \& Schepers, B (2014) Eindrapport WROOV-Light 2007 - 2011, Zoetermeer.

Van de Velde, D (1999) "Organisational forms and entrepreneurship in public transport: classifying organisational forms," in: Transport Policy, pp. 147-157.

Williamson, O (2000) "The new institutional economics: taking stock, looking ahead," in: Journal of economic literature, pp. 595-613.

Witbreuk, M (1997) "Het regionale verkeersnetwerk als common pool resource: de effectiviteit van samenwerking," , pp. 1-231.

Witbreuk, M (2000) "Regional transport networks and institution building: The role of co-operation," in South African transport conference,pp. 17-20. 